\title{
Influence of Season and Intensity of Defolia- tion on Bluebunch Wheatgrass Survival and Vigor in Southern British Columbia
}

\author{
ALASTAIR MCLEAN AND SANDRA WIKEEM
}

\begin{abstract}
Bluebunch wheatgrass (Agropyron spicatum Pursh) Scribn. \& Smith) response to various clipping regimes which incorporated different times, frequencies, and intensities of defoliation was examined in southern British Columbia. The experiment was repeated for 3 consecutive years at a low $(296 \mathrm{~m})$ and a high $(1,112$ m) elevation site. Plant survival and vigor was evaulated the summer following defoliation. Greatest injury was incurred by treatments involving defoliation to a 5-cm stubble height from mid April to the end of May or from early May to mid June at the low and high elevation sites, respectively. Reduced injury occurred from treatments which left 10 or $15-\mathrm{cm}$ stubble heights or which ceased defoliation earlier in the season. No appreciable damage was incurred by fall clipping to $5 \mathrm{~cm}$ or by season-long defoliation to $20 \mathrm{~cm}$. Injury resulting from spring plus fall as compared to spring only defoliation was inconsistent. Greatly reduced injury for many treatments at the low elevation site in one year was attributed to unusually warm spring temperatures and attendant rapid spring growth.
\end{abstract}

Bluebunch wheatgrass (Agropyron spicatum (Pursh) Scribn. and Smith) reaches the northern limits of its distribution on the grasslands of southern British Columbia. Although the species has been studied extensively in the United States, we wished to confirm application of this work, in particular, response to season of defoliation, to southern British Columbia. This information is required for grazing management planning.

This study formed part of a larger project on the autecology of bluebunch wheatgrass. Quinton et al. (1982) examined vegetative and reproductive growth of the species in relation to weather. They found that bluebunch wheatgrass in the Kamloops area started growth immediately after snow melt. Growth ceased from 7 May to 15 July and plants fully matured from 7 July to 10 August, depending on site and elevation. Fall regrowth was not predictable, occurring in only 1 of the 3 years of study.

Effects of defoliation injury on bluebunch wheatgrass are well documented; basal area, stem numbers and both root and forage yields are reduced and mortality can be high (Hanson and Stoddart 1940, Branson 1956, Mueggler 1972, Bleak and Keller 1973, Caldwell et al. 1981). The species recovers vigor slowly, with an estimated rest period of 8 to 10 years required for complete recovery following severe defoliation (Mueggler 1975).

Response at various seasons or phenological stages has been examined in several regions to determine when bluebunch wheatgrass is most and least susceptible to defoliation. Total herbage removal (clipping) in late spring incurred great mortality and subsequent reduction of vigor of surviving plants in southeastern Washington but grazing to a similar extent during the summer and fall appeared to have little detrimental effect (Daubenmire 1940). In Utah (Stoddart 1946), defoliation during mid to late May

\footnotetext{
Authors are range ecologist and ecology technician, Agriculture Canada, Range Research Station, Kamloops, B.C. 604-376-5565

The authors express their appreciation to Larry Haupt for technical help, to Dr. Dee Quinton for his critical review of the manuscript, and to John Hall, Research Station, Agriculture Canada, Vancouver, B.C., for statistical assistance.

Manuscript accepted March 7, 1984.
}

caused greatest mortality within 1 year of clipping. However, all defoliation at dates other than very early in the spring or in the fall resulted in heavy mortality. Date of cessation of clipping was suggested as the factor of greatest importance in plant survival since plants not clipped after mid May suffered no mortality. In Idaho (Blaisdell and Pechanec 1949), plants subject to a single defoliation to ground level were most susceptible if clipped in late May and early June. Late April and early May clipping caused moderate yield reductions in subsequent years while plants clipped in fall showed no yield reduction. In both the Utah and Idaho studies, the time of greatest susceptibility corresponded to the late boot or "heads emerging" stage of bluebunch wheatgrass phenology. The boot stage (mid May) was also very susceptible to defoliation injury in a Washington study (Wilson et al. 1960). At this stage carbohydrate reserves were low and the plants were unable to regrow. Less injury occurred when the clipping height was $20 \mathrm{~cm}$ as compared to $10 \mathrm{~cm}$. The lack of difference observed between the ground level and $10-\mathrm{cm}$ stubble height was attributed to the steminess and scarcity of leaves in the first $10 \mathrm{~cm}$.

The purpose of the present study was to compare bluebunch wheatgrass response in southern British Columbia to a number of clipping regimes which incorporate different times, frequencies, and intensities of defoliations in order to determine when bluebunch wheatgrass is most susceptible to injury. Plant survival was of greatest interest but characteristics related to plant vigor were examined also. Clipping treatments in this study do not realistically simulate cattle grazing, as, except for cases of extreme overutilization, grazing would not remove the entire phytomass to such low stubble heights at such regular intervals. However, the study does show bluebunch wheatgrass response to defoliation at various times throughout the growing season and does indicate times of greatest susceptiblity in southern British Columbia.

\section{Study Areas}

The Tranquille site ( $296 \mathrm{~m}$ elevation) was chosen to represent the lower grassland or the big sagebrush (Artemisia tridentata Nutt.)bluebunch wheatgrass zone (McLean and Marchand 1968). The site, $5 \mathrm{~km}$ northwest of Kamloops, faced southeast on a gentle (1 to $3 \%$ ) slope. Average annual precipitation was $24 \mathrm{~cm}$. The soil, a Brown Chernozemic (Aridic Boroll) sandy loam, had developed on colluvium over lacustrine deposits. Because of a long-standing fence, the range was in excellent condition.

The Minnie Lake site, $21 \mathrm{~km}$ southeast of Quilchena, represented the upper grassland or bluebunch wheatgrass-rough fescue (Festuca scabrella Torr.) zone. The site faced southeast on a gentle (5\%) slope and had an elevation of $1,112 \mathrm{~m}$. The soil was an Eluviated Dark Grey Chernozem (Borallic Boroll) of sandy loam texture, derived from morainal deposits. The average annual precipitation was $30.5 \mathrm{~cm}$. The site, which had received light winter grazing prior to the construction of an exclosure in 1968, was in good, approaching excellent, range condition. Further details on sites are given in Quinton et al. (1982). 
1

2

3

4

5

6

7

8

9

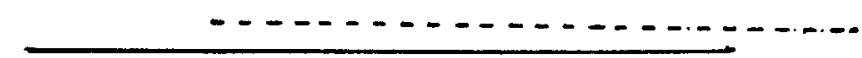

$\ldots \ldots$

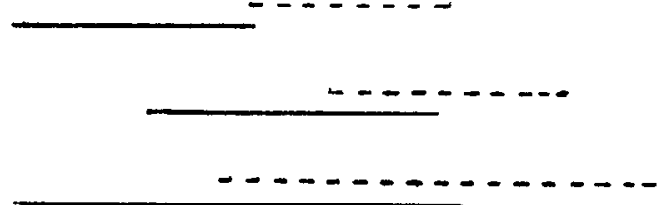

$-----\cdots$

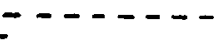

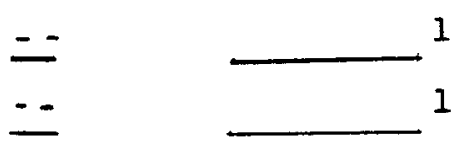

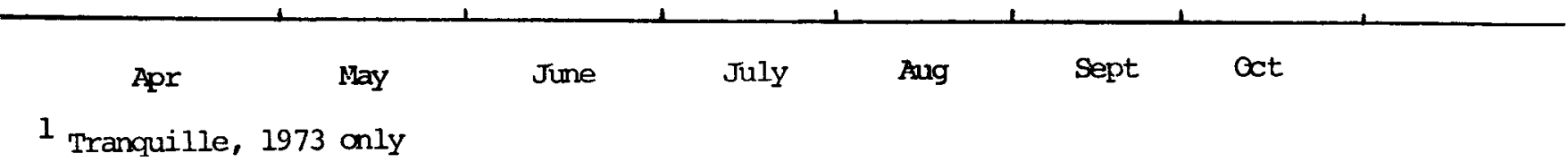

Fig. 1. Clipping schedule at Tranquille (

\section{Experimental Procedure}

We used 10 clipping treatments to simulate timing and duration of possible grazing regimes. Six treatments differed in date and/or frequency of defoliations while the remaining 4 varied only in clipping intensity (stubble height). A control (no defoliation) was included as a check for phenological development and natural mortality. The experiment was repeated for 3 years. Plants were clipped weekly according to the schedule given in Figure 1. Because of the cooler temperatures at Minnie Lake, onset of cutting was delayed until mid to late April, when spring growth was initiated. Duration of cutting for treatments $1,8,9$, and 10 varied for site and year, as clipping continued until cessation of growth. Since the treatments were applied at similar stages of plant growth, modifications to the clipping schedule should not have greatly influenced the outcome. At the onset of the experiment, plants in treatments 2 , 3 , and 7 were designated to be cut weekly through September and October, but regrowth was insignificant in most cases. Instead, plants were clipped once in early September, to remove all regrowth since the last spring cutting. In addition to the early September defoliation, regrowth at Tranquille was sufficient in 1973 to allow 3 weekly clips from mid to late October. This was the only case of repeated fall clipping.

Experimental design was completely randomized. Prior to spring clipping, 10 vigorous bluebunch wheatgrass plants (replicates) per treatment and control were selected randomly from pure stands at both sites. Different plants were used for each year of the
Clipping heights were $5 \mathrm{~cm}$ unless otherwise noted. Dates are approximate. study. Selected plants were staked out, labelled, and basal areas were measured with an area-list ruler. During clipping, herbage was removed to $5 \mathrm{~cm}$ unless otherwise indicated for the treatment. Phenological stage and leaf and culm height were measured on control plants weekly throughout the clipping schedule.

Clipping treatment effects were observed in late June to early July the summer following clipping. Percent kill was visually estimated on each plant to assess mortality. Plant vigor was appraised by measuring leaf height, counting vegetative and flowering culms, and clipping plants to measure yield.

Thermographs in Stevenson screens and Victor rain gauges monitored air temperature and rainfall at each site. At biweekly intervals from April to September, soil temperatures at $10 \mathrm{~cm}$ were recorded. Also, soil samples were collected at 10 and $25 \mathrm{~cm}$ for gravimetric moisture content determinations.

Clipping treatment, location, and year effects were statistically analyzed using analysis of variance. Covariance analysis was used for tiller number, with basal area acting as a covariate. No other variable was detectably related to basal area. Data transformations were considered for percent kill (arc sine), leaf height (log), number of tillers (square root) and number of flowering culms $(\log X+1)$, but only the latter resulted in an improved analysis.

Each variable was analyzed with sites and years combined (three-factor analysis) except for number of flowering culms. This variable was analyzed only at the Tranquille site in 1973 due to insufficient culm production in other cases. Percent kill, the variable of primary interest, was analyzed for each site in each year 
Table 1. Average percent kill of bluebunch wheatgrass plants in summer the year following clipping.

\begin{tabular}{|c|c|c|c|c|c|c|c|}
\hline \multirow[b]{2}{*}{ Treatment number } & \multirow{2}{*}{$\begin{array}{l}\text { Pooled means } \\
\text { ( } 3 \text { yrs) }\end{array}$} & \multicolumn{3}{|c|}{ Tranquille } & \multicolumn{3}{|c|}{ Minnie Lake } \\
\hline & & 1971 & 1972 & 1973 & 1971 & 1972 & 1973 \\
\hline $\begin{array}{r}1 \\
2 \\
3 \\
4 \\
5 \\
6 \\
7 \\
8 \\
9 \\
10 \\
11\end{array}$ & $\begin{array}{c}92 \mathrm{~g}^{1} \\
42 \mathrm{~d} \\
81 \mathrm{fg} \\
78 \mathrm{fg} \\
71 \mathrm{ef} \\
30 \mathrm{~cd} \\
8 \mathrm{ab} \\
58 \mathrm{e} \\
24 \mathrm{bc} \\
12 \mathrm{ab} \\
4 \mathrm{a}\end{array}$ & $\begin{array}{l}99 \mathrm{e} \\
27 \mathrm{c} \\
94 \mathrm{e} \\
91 \mathrm{e} \\
95 \mathrm{e} \\
23 \mathrm{bc} \\
10 \mathrm{a} \\
53 \mathrm{~d} \\
29 \mathrm{c} \\
14 \mathrm{ab} \\
4 \mathrm{a}\end{array}$ & $\begin{array}{r}99 \mathrm{e} \\
23 \mathrm{~b} \\
93 \mathrm{e} \\
92 \mathrm{e} \\
80 \mathrm{~d} \\
19 \mathrm{~b} \\
5 \mathrm{a} \\
59 \mathrm{c} \\
22 \mathrm{~b} \\
9 \mathrm{a} \\
0 \mathrm{a}\end{array}$ & $\begin{array}{l}62 \mathrm{de} \\
37 \mathrm{bc} \\
50 \mathrm{cde} \\
65 \mathrm{e} \\
40 \mathrm{bcd} \\
21 \mathrm{ab} \\
11 \mathrm{a} \\
41 \mathrm{bcd} \\
5 \mathrm{a} \\
4 \mathrm{a} \\
3 \mathrm{a}\end{array}$ & $\begin{array}{l}99 \mathrm{f} \\
69 \mathrm{~d} \\
79 \mathrm{de} \\
92 \mathrm{ef} \\
93 \mathrm{ef} \\
65 \mathrm{~d} \\
6 \mathrm{a} \\
67 \mathrm{~d} \\
49 \mathrm{c} \\
25 \mathrm{~b} \\
4 \mathrm{a}\end{array}$ & $\begin{array}{l}97 \mathrm{~g} \\
45 \mathrm{~d} \\
92 \mathrm{~g} \\
73 \mathrm{ef} \\
80 \mathrm{f} \\
22 \mathrm{c} \\
11 \mathrm{ab} \\
68 \mathrm{e} \\
18 \mathrm{bc} \\
9 \mathrm{ab} \\
6 \mathrm{a}\end{array}$ & $\begin{array}{l}93 \mathrm{f} \\
47 \mathrm{de} \\
78 \mathrm{f} \\
56 \mathrm{e} \\
41 \mathrm{cde} \\
32 \mathrm{bcd} \\
3 \mathrm{a} \\
49 \mathrm{de} \\
21 \mathrm{abc} \\
14 \mathrm{ab} \\
1 \mathrm{a}\end{array}$ \\
\hline $\begin{array}{l}\text { Avg all treatments } \\
\text { SE }^{2}\end{array}$ & $\begin{array}{l}45 \\
5.5\end{array}$ & $\begin{array}{l}49 \\
3.5\end{array}$ & $\begin{array}{l}46 \\
3.3\end{array}$ & $\begin{array}{l}31 \\
7.4\end{array}$ & $\begin{array}{l}59 \\
5.2 \\
\end{array}$ & $\begin{array}{l}47 \\
3.6 \\
\end{array}$ & $\begin{array}{l}42 \\
7.5 \\
\end{array}$ \\
\hline
\end{tabular}

'Means in columns followed by the same letter are judged not different by Duncan's multiple range test. $P \leqq 0.05$.

${ }^{2} n=60$ for pooled analysis, $n=10$ for individual site-years.

(one-factor analysis) in addition to the combined analysis.

In the combined analysis, year, a random effect, was considered as a replication. Because variability attributed to the year-bytreatment (location and clipping) interaction exceeded experimental error variation, the interaction was used to test the main effects. The third-order interaction term (year $X$ location $X$ clipping) was used as a measure of error for yield, as there was only one observation per experimental unit. Clipping treatment means were separated with Duncan's multiple range test ( $P \leqq 0.05)$.

\section{Results}

\section{Weather}

Weather data tables are presented in Quinton et al. (1982). Tranquille was the warmer and drier site. It averaged about $5^{\circ} \mathrm{C}$ warmer from April to October, while precipitation over the same period averaged about $6 \mathrm{~cm}$ greater at Minnie Lake. At both locations July and August were the hottest months while April and Ocober were the coolest. June was the wettest month for both sites and April was the driest.

Temperature and precipitation patterns varied among years. Temperatures were noticeably above average in August 1971 and in September 1973. The wettest year was $1972 ; 1971$ was intermediate and 1973 was the driest. Even though fall rainfall was considerably above average, the exceptionally low precipitation in June and July explains the low 1973 seasonal total. Yearly weather variations were not always reflected equally at each site. For example, the mean April 1972 temperature was $2^{\circ} \mathrm{C}$ below average at Tranquille but was $1^{\circ} \mathrm{C}$ above the mean at Minnie Lake.

Soil temperatures $(10 \mathrm{~cm}$ depth) and average air temperatures followed similar seasonal patterns. Soils were cool in April (Tranquille $10^{\circ} \mathrm{C}$, Minnie Lake $4^{\circ} \mathrm{C}$ ), warmed to peak temperatures in July and August (Tranquille $22^{\circ} \mathrm{C}$, Minnie Lake $17^{\circ} \mathrm{C}$ ), then dropped back to April levels by October. Minnie Lake soils were about $6^{\circ} \mathrm{C}$ cooler than Tranquille's through the growing season. High June and July temperatures increased April-October averages at both sites in 1973, but in no year was each month consistently higher than in other years.

Average soil moisture at $25 \mathrm{~cm}$ was highest in April (Tranquille $20 \%, 15 \%$ Minnie Lake), then gradually decreased to a low (10\% Tranquille, 6\% Minnie Lake) in August. August and September showers raised soil moisture considerably in some years (e.g., Tranquille 1973) but the fall values remained lower than spring. Seasonal average soil moisture was lowest in 1973 (Tranquille $11 \%$, Minnie Lake 9\%), the year of lowest precipitation. It was highest at Minnie Lake in $1972(12 \%)$ the wettest year, but was highest at Tranquille in 1971 (14\%).

Despite higher precipitation at Minnie Lake, the Tranquille soils frequently were moister during the study, especially at the $25 \mathrm{~cm}$ depth. Quinton et al. (1982) suggested that the presence of more organic matter in the surface horizon at the Minnie Lake site may have delayed water penetration thus increasing potential evaporation losses to wind. Deeper infiltration of water in coarse-textured subsoils at Tranquille might explain the enigma of moister soils on a site with lower precipitation.

\section{Percent Kill}

Plant mortality varied significantly among the clipping regimes for each site in all years and when sites and years were pooled (Table 1).

The pooled mean reveals extremely high mortality ( $92 \%$ kill) when plants were subjected to weekly defoliation to $5 \mathrm{~cm}$ throughout the entirc growing season (treatment 1). Mortality was also severe on treatments 3,4 , and 5, all of which were clipped from mid April to the end of May at Tranquille and early May to mid June at Minnie Lake. Moderate to heavy mortality resulted from treatment 6 (April or May clipping at Tranquille and Minnie Lake, respectively), treatment 2 (April or May + fall clipping), and treatments 8 and 9 (season-long clipping to 10 - and $15-\mathrm{cm}$ stubble height, respectively). Fall clipping only (treatment 7) and seasonlong clipping to $20-\mathrm{cm}$ stubble height (treatment 10 ) did not result in statistically greater percent kill than the unclipped control (treatment 11). Percent kill increased linearly as the stubble height decreased.

Overall means for fall and spring clipping treatments were not significantly different from spring clipping only treatments. Examination of each site in individual years, however, reveals some differences. At the Tranquille site, treatment-3 plants which were clipped mid April to end of May and September in 1972, suffered greater mortality than treatment-5 plants clipped in spring only. At the Minnie Lake site, mortality of treatment-3 plants exceeded that of treatment-5 plants in 1972 and 1973 . Percent kill was greater also at Minnie Lake in 1972 on treatment-2 (May + fall) than on treatment-6 (May only) plants.

While actual percent kill varied with location and year, the relative mortality observed for most clipping treatments was constant. For example, mortality resulting from treatment 1 was consistently among the highest while that of treatment 7 was among the lowest. There were exceptions, however, the most striking of which occurred with treatment 5 . This clipping treatment usually resulted in very severe plant injury, but plants from the 1973 clippings at both sites experienced only moderate damage.

Mortality averaged over the 3 years of study was significantly higher on the Minnie Lake site $(49 \%)$ than on the Tranquille site $(42 \%)$ but in 1972 average percent kill at the 2 sites was similar. Minnie Lake plants had the highest 3-year average mortality for 
most clipping treatments, but some treatments showed little difference and treatment- 4 plants suffered greater mortality at Tranquille (average 83 vs $74 \%$ kill). However, there was no statistically significant location by clipping treatment interaction. There was a highly significant year effect. Overall mortality was 54.0, 46.4 and $36.1 \%$ for 1971,1972 , and 1973 respectively. There was also a year by clipping treatment and location interaction which likely occurred because of the greatly reduced mortality at Tranquille in 1973, which did not occur to as great an extent at Minnie Lake

\section{Leaf Height, Tiller Number, Yield, and Number of Flowering Culms}

The variables leaf height, tiller number, and foliage yield-all indicators of plant vigor-corroborated the percent kill results. Length of leaves, number of tillers, and yields were highest for clipping treatments which had the greatest plant survival. Means of these variables were arrayed similarly to percent kill by Duncan's multiple range test (Table 2). All 3 variables increased linearly with clipping height.

Table 2. Leaf height, tiller number and yields of the various clipping treatments the year following clipping averaged over the three years and both sites.

\begin{tabular}{lccc}
\hline \hline Treatment number & $\begin{array}{c}\text { Leaf height } \\
(\mathrm{cm})\end{array}$ & $\begin{array}{c}\text { Tiller number' } \\
\text { per plant }\end{array}$ & $\begin{array}{c}\text { Yield }(\mathrm{g}) \\
\text { per plant }\end{array}$ \\
\hline 1 & $11.5 \mathrm{a}^{2}$ & $21.2 \mathrm{a}$ & $0.61 \mathrm{a}$ \\
2 & $22.0 \mathrm{cde}$ & $100.6 \mathrm{c}$ & $3.42 \mathrm{bc}$ \\
3 & $17.9 \mathrm{bc}$ & $37.2 \mathrm{ab}$ & $1.34 \mathrm{a}$ \\
4 & $14.9 \mathrm{ab}$ & $36.2 \mathrm{ab}$ & $0.84 \mathrm{a}$ \\
5 & $17.1 \mathrm{bc}$ & $50.8 \mathrm{ab}$ & $1.47 \mathrm{ab}$ \\
6 & $25.1 \mathrm{ef}$ & $104.2 \mathrm{c}$ & $4.32 \mathrm{~cd}$ \\
7 & $27.7 \mathrm{f}$ & $157.8 \mathrm{~d}$ & $7.76 \mathrm{f}$ \\
8 & $19.3 \mathrm{bcd}$ & $65.2 \mathrm{~b}$ & $2.17 \mathrm{ab}$ \\
9 & $24.3 \mathrm{def}$ & $127.3 \mathrm{c}$ & $5.66 \mathrm{de}$ \\
10 & $27.4 \mathrm{f}$ & $160.3 \mathrm{~d}$ & $6.99 \mathrm{ef}$ \\
11 & $28.7 \mathrm{f}$ & $174.3 \mathrm{~d}$ & $8.35 \mathrm{f}$ \\
SE $^{3}$ & 1.7 & 10.4 & 0.63 \\
\hline
\end{tabular}

Tiller number means adjusted for basal area.

Means in columns followed by the same letter are judged not different by Duncan's multiple range test. $P \leq 0.05$

${ }^{3} n=60$ for leaf height and tiller, number, $n=6$ for yield.

The outcome of the analysis of variance for leaf height was similar to that of percent kill. Average leaf height was significantly taller at Tranquille $(23 \mathrm{~cm})$ than at Minnie Lake $(20 \mathrm{~cm})$. There was no significant location by clipping treatment interaction. The year effect was significant (average leaf height of 22,17 , and $26 \mathrm{~mm}$ for 1971,1972 , and 1973, respectively) as was the year by location and clipping interaction. As with percent kill, the Tranquille site in 1973 appeared to be the cause of the interaction as leaf height at Tranquille in $1973(30 \mathrm{~cm})$ was higher than in $1971(22 \mathrm{~cm})$ and $1972(17 \mathrm{~cm})$ but the 1973 leaf height at Minnie Lake $(21 \mathrm{~cm})$ was similar to $1971(22 \mathrm{~cm})$. Average leaf heights at the 2 sites were identical in 1971 and 1972.

Tiller numbers did not differ significantly between locations. However, the year effect and the year by location and clipping treatment interaction were significant. Average tiller number (adjusted to remove basal area effect) varied from a low of 84 per plant in 1972, to 89 in 1971, and 109 in 1973. The interaction again likely resulted from the Tranquille site in 1973 which had an elevated average tiller number of 118 compared with 87 in 1971 and 72 in 1972. The Minnie Lake site did not show as great an increase with 101 tillers per plant in 1973 compared with 92 and 96 for 1971 and 1972 , respectively.

Yields taken the year after clipping differed among clipping years but not between sites. Again, an interaction resulted from the Tranquille plants clipped in 1973 , whose average yield $(7.6 \mathrm{~g} / \mathrm{plant})$ was substantially greater than the average Minnie Lake yield (4.3 g/plant).
Number of flowering culms could be analyzed for only the Tranquille site in 1973 as culm production was virtually nil in all other cases. Analysis of log-transformed data reveal differences among clipping treatments similar to those observed with the other variates (Table 3). Greatest production of flowering culms occurred on treatments with the least mortality and vice versa.

Table 3. Average flowering culm production per plant in summer 1974 at the Tranquille site on plants clipped in 1973.

\begin{tabular}{lcl}
\hline Treatment number & $\begin{array}{c}\text { Average number } \\
\text { per plant }\end{array}$ & $\begin{array}{c}\text { Average log number } \\
\text { per plant }\end{array}$ \\
\hline 1 & 2.3 & $0.319 \mathrm{a}^{\mathbf{1}}$ \\
2 & 3.5 & $0.265 \mathrm{a}$ \\
3 & 10.4 & $0.634 \mathrm{abc}$ \\
4 & 1.0 & $0.185 \mathrm{a}$ \\
5 & 10.5 & $0.579 \mathrm{abc}$ \\
6 & 15.1 & $0.894 \mathrm{bc}$ \\
7 & 25.8 & $1.095 \mathrm{~cd}$ \\
8 & 4.7 & $0.540 \mathrm{ab}$ \\
9 & 57.1 & $1.535 \mathrm{~d}$ \\
10 & 45.9 & $1.446 \mathrm{~d}$ \\
11 & 35.4 & $1.452 \mathrm{~d}$ \\
SE $(\mathrm{n}=10)$ & & 0.171 \\
\hline
\end{tabular}

${ }^{1}$ Means in the column followed by the same letter are judged not different by Duncan's multiple range test. $P \leq 0.05$.

\section{Discussion}

Despite the presence of interactions between years and treatments and differences among years and sites, the data reveal consistent patterns of plant response to the different treatments. Any treatment involving clipping bluebunch wheatgrass to $5 \mathrm{~cm}$ through the latter part of April to the end of May at Tranquille, or from mid May to late June at Minnie Lake (treatments 1, 3, 4, 5) resulted in high mortality and reduced vigor in surviving plants. Clipping for these treatments started when the plants were still in the vegetative stage and continued for all (treatment 1) or nearly all (treatments 3,4,5) of the leaf-growth period (Quinton et al. 1982). Late spring defoliation which precluded regrowth prior to the summer dormancy also caused greatest injury in a Utah study (Stoddart 1946).

Carbohydrate concentrations in bluebunch wheatgrass roots and stem bases reach the annual minimum either during the middle of the spring vegetative stage (McIlvanie 1942, Hyder and Sneva 1963 ) or during the early boot stage (Daer and Willard 1981, Donart 1969). Bluebunch wheatgrass is notably slow to reach carbohydrate seasonal minimums, and produces proportionately more spring growth than other species (McIlvanie 1942, Donart 1969). The combination of defoliation at a vulnerable stage, bluebunch wheatgrass's apparent reliance on reserves for spring growth, and the inopportunity for reserve replenishment before the summer dormancy ensures that plants subjected to late April through May clippings enter winter in a carbohydrate-depleted state.

Clipping through the same time interval but leaving more foliage intact (treatments 8 and 9) resulted in somewhat reduced damage, which suggests some reserve replenishment. Wilson et al. (1960) observed improved yields on plants subjected to $20-\mathrm{cm}$ clipping height, as compared to 0 - and $10-\mathrm{cm}$ heights although there was little difference between 0 and $10 \mathrm{~cm}$. In the present study, removal of herbage to $20 \mathrm{~cm}$ through the late April and May period (treatment 10 ) produced no deleterious effects. Relatively little herbage was removed with this treatment as maximum seasonal leaf height of unclipped plants averaged about $31 \mathrm{~cm}$ for both sites.

Although stubble height was only $5 \mathrm{~cm}$ for treatments 2 and 6 , mortality ranged from moderate to heavy rather than severe. Cessation of clipping for these treatments occurred prior to completion of leaf growth. Comparison of dates of last clipping with 
cessation of leaf growth (Quinton et al. 1982) reveals a period of continued growth of about 5 weeks and 6 weeks at Tranquille and Minnie Lake, respectively, except for 1973 when the values were 1 and 5 weeks. Stoddart (1946) and Blaisdell and Pechanec (1949) also observed reduction of injury on early-clipped plants that were given time to regrow. Stoddart emphasized the importance of allowing spring grazed bluebunch wheatgrass opportunity for regrowth prior to the dormant period in areas of little or no summer growth. Regrowth, measured on 1 September, averaged $3.6 \mathrm{~g}$ for treatment-2 plants but was only $0.5 \mathrm{~g}$ for treatment-3 plants. This yield difference should also reflect a difference in above-ground carbohydrate pools (concentration multiplied by biomass). Caldwell et al. (1981) observed greatly reduced carbohydrate pools in defoliated bluebunch wheatgrass plants which were never replenished to the level of the unclipped controls during the growing season. Carbohydrate pools may be a more appropriate expression of plant carbohydrates than concentrations since fluctuations in biomass components can be accounted for.

Fall clipping alone did not have a deleterious effect on bluebunch wheatgrass survival or vigor, even in 1973 when at Tranquille, regrowth was considerable. This suggests that fall plant reserve accumulation is minor relative to that in the spring.

The impact of the various treatments on meristematic tissue may partially explain some of the observed results. For example, treatments which either avoided significant meristem removal by early cessation of clipping $(2,6)$ or treatments which delayed and/or minimized removal by virtue of clipping height $(8,9,10)$ tended to produce less injury. Meristem retention is desirable when leaf development is incompletc since photosynthetic tissue can be replaced by continued leaf expansion rather than through the slower process of tillering (Dahl and Hyder 1977). Meristem removal may be beneficial though, when leaf expansion is complete, as presence of stem apices inhibits axillary bud initiation and tiller development (Rechenthin 1956, Youngner 1972).

The role of meristems in bluebunch wheatgrass defoliation has not been decided conclusively. 'Whitmar' beardless wheatgrass, a selection of bluebunch wheatgrass, produced reproductive shoots which had nearly completed leaf expansion by 1 May when culm elongation was just beginning (Hyder and Sneva 1963). Elevation of heads above $5 \mathrm{~cm}$ ( $2 \mathrm{in}$ ), a height vulnerable to grazing, and appearance of axillary buds did not occur until 2 weeks later. The authors did not clip the plants but defoliation at this point might be expected to stimulate tiller development. Caldwell et al. (1981) clipped bluebunch wheatgrass to $5 \mathrm{~cm}$ at the 4-5 leaf stage and again 2 weeks later, presumable when leaf growth was near completion and when stem apices were exposed, yet no new tillers were produced. Younger (1972) suggested that inconsistent tillering responses relate to photosynthate supply and apical dominance. Thus low carbohydrate pools following defoliation in Caldwell's study could explain the absence of tillering.

Defoliation response may be related to development of future meristems as well as the removal of those already present. Since meristems arise from basal axillary buds formed in the previous year (Hyder and Sneva 1963), amount and vigor of tillers reflects past influences on the plant. Severe defoliation would arrest bud development by intcrupting photosynthate supply but bud activity could resume given adequate regrowth. Removal of regrowth in the fall, in addition to spring defoliation, may preclude full bud development and thus result in reduced vigor the following year.

It is difficult to understand why clipping in fall and spring affects plant survival and vigor inconsistently, relative to spring clipping alone. Possibly high variability among replicates may have screened some differences, e.g., treatments 2 and 6 at both sites in 1973; however, in other cases (e.g., treatments 2 and 6 at both sites in $1971)$ the results were virtually identical. Fall regrowth does seem to have some effect since kill differed most between spring only versus spring plus fall defoliation treatments when regrowth was greatest. For example, percent kill differed significantly between treatments 2 and 6 at Tranquille in 1972 when regrowth averaged $5.1 \mathrm{~g} /$ plant but not in 1971 or 1973 when regrowth was only 2.7 and $1.6 \mathrm{~g} /$ plant, respectively.

Stoddart (1946) also observed variable response to spring-plusfall versus spring-only clipping. When bluebunch wheatgrass was clipped to $2.5 \mathrm{~cm}$ stubble height, mortality from spring clipping was only $25 \%$ compared to $65 \%$ for plants clipped spring and fall. However, when the stubble height was $5 \mathrm{~cm}$, mortality was identical for both clipping treatments. Because of the inconsistent results in both studies, it is not possible to determine conclusively if defoliation in fall as well as spring causes additional plant injury. It is difficult to arrive at the reason for the inconsistent results since plant response is often related to the interacting factors of weather rather than only one parameter. The effects of soil moisture levels in the fall, for example, can be made more severe by cold winds and low temperatures followed by a warm spell. Also, weather factors may have been operating at a time that was not recorded, for example, a frost may have occurred between sampling times, or weather conditions from the previous fall may have influenced results.

The most strikingly inconsistent plant response occurred from the Tranquille 1973 clipping where many treatments resulted in substantially reduced injury as compared with earlier years. Treatments previously causing damage $(1,3,4,5)$ as well as some causing more moderate injury $(8,9)$ exhibited this effect. Quinton et al. (1982) remarked on the exceptional yield at the Tranquille site in 1973 and suggested that warm March soil temperatures may have stimulated rapid early growth. Early production of phytomass (approximately $4 \mathrm{~g}$ dry weight per plant by 1 April) may have allowed substantial accumulation of plant reserves prior to the onset of clipping. Regrowth following clipping was rapid, probably as a result of the warm $\left(12^{\circ} \mathrm{C}\right.$ by 1 April) soil temperatures.

More injury might have been expected from the repeated defoliations through this active growth phase because of regrowth demands for carbohydrate reserves. The role of carbohydrate reserves on regrowth is controversial but it appears likely that reserves may be utilized for a short time following defoliation until new photosynthetic materials become active (Younger 1972, White 1973, Trlica 1977). Perhaps in this study, rate and quantity of new growth were sufficient to offset negative effects of defoliation. Treatments 2 and 6 did not show a similar decrease in injury compared with other years, nor did treatments 7,10 , and 11 (the control). Perhaps the degree of injury was too moderate for the plants to benefit from the increased spring growth. In the case of treatments 2 and 6 , less time between cessation of clipping and cessation of growth existed in 1973 than in other years. Less opportunity for carbohydrate accumulation may have balanced the benefits offered by early growth.

Much of the difference between the Minnie Lake and Tranquille sites can be attributed to the 1973 response as the Minnie Lake site did not experience substantially reduced plant injury. Unlike the Tranquille site, there was no early spurt in growth and cumulative phytomass yield during the early season did not differ greatly from 1971 and 1972. Treatment 2, and to a lesser extent treatment 6 (which was similar to treatment 2 except there was no fall clipping), caused greater mortality at the Minnie Lake location in every year of the study. This was unexpected as both sites were clipped at the same phenological stages and there was a longer growth period following cessation of clipping at the Minnie Lake site.

\section{Literature Cited}

Blaisdell, J.P., and J.F. Pechanec. 1949. Effects of herbage removal at various dates on vigor of bluebunch wheatgrass and arrowleaf balsamroot. Ecol. 30:298-305.

Bleak, A.T., and W. Keller. 1973. Water requirements, yield and tolerance to clipping of some cool-season, semiarid range grasses. Crop Sci. $13: 367-370$

Branson, F.A. 1956. Quantitative effects of clipping treatments on five range grasses. J. Range Manage. 9:86-88. 
Caldwell, M.M., J.H. Richards, D.A. Johnson, R.S. Nowak, and R.S. Dzurec. 1981. Coping with herbivory: Photosynthetic capacity and resource allocation in two semiarid Agropyron bunchgrasses. Oecologia (Berl) 50:14-24.

Daer, T., and E.E. Willard. 1981. Total nonstructural carbohydrate trends in bluebunch wheatgrass related to growth and phenology. J. Range Manage. 34:377-379.

Dahl, B.E., and D.N. Hyder. 1977. Developmental morphology and management implications. P. 258-290. In: R.E. Sosebee (ed.) Rangeland Plant Physiology. Range Sci. Series No.4, Soc. Range Manage., Denver, Colo.

Daubenmire, R.F. 1940. Plant succession due to overgrazing in the Agropyron bunchgrass prairie of southeastern Washington. Ecol. 21:55-64.

Donart, G.B. 1969. Carbohydrate reserves of six mountain range plants as related to growth. J. Range Manage. 22:411-415.

Hanson, W.R., and L.A. Stoddart. 1940. Effects of grazing upon bunch wheatgrass. J. Amer. Soc. Agron. 32:278-289.

Hyder, D.N., and F.A. Sneva. 1963. Studies of six grasses seeded on sagebrush bunchgrass range: yield, palatability, carbohydrate accumulation, and developmental morphology. Oregon Agr. Exp. Sta. Tech. Bull. 71.

McIlvanie, S.K. 1942. Carbohydrate and nitrogen trends in bluebunch wheatgrass, Agropyron spicatum, with special reference to grazing influences. Plant Physiol. 17:540-557.
McLean, A., and L. Marchand. 1968. Grassland ranges in southern interior of British Columbia. Can. Dept. Agr. Pub. 1319.

Mueggler, W.F. 1972. Influence of competition on the response of bluebunch wheatgrass to clipping. J. Range Manage. 25:88-92.

Mueggler, W.F. 1975. Rate and pattern of vigor in Idaho fescue and bluebunch wheatgrass. J. Range Manage. 28:198-204.

Quinton, D.A., A. MeLean, and D.G. Stout. 1982. Vegetative and reproductive growth of bluebunch wheatgrass in interior British Columbia. J. Range Manage. 35:46-51.

Rechenthin, C.. 1956. Elementary morphology of grass growth and how it affects utilization. J. Range Manage. 9:167-170.

Stoddart, L.A. 1946. Some physical and chemical responses of Agropyron spicatum to herbage removal at various seasons. Utah Agr. Exp. Sta. Bull. 324.

Trlica, M.J. 1977. Distribution and utilization of carbohydrate reserves in range plants P. 73-96. In: R.E. Sosebee (ed.) Rangeland Plant Physiology. Range Sci. Series No. 4, Soc. for Range Manage., Denver, Colorado.

White, L.M. 1973. Carbohydrate reserves of grasses: a review. J. Range Manage. 26:13-18.

Wilson, A.M., G.A. Harris, and D.H. Gates. 1960. Cumulative effects of clipping on yield of bluebunch wheatgrass. J. Range Manage. 19:90-91.

Youngner, V.B. 1972. Physiology of defoliation and regrowth. p. 292-303. In: V.B. Younger and C.M. McKell (eds.) The Biology and Utilization of Grasses. Academic Press, New York. 